\title{
11
}

\section{What Do We Talk About When We Talk About Credibility? Refugee Appeals in Italy}

\author{
Barbara Sorgoni
}

\section{Introduction}

In this chapter I focus on a specific moment in the Italian procedure for granting international protection, the first level of appeal. In Italy, asylum seekers should apply for protection upon their arrival in the country, filling in a form (Modulo $\mathrm{C} / 3$ ) at a police headquarters. They are usually hosted in different types of centres while they wait for their hearing in front of a Territorial Commission (TC), the administrative board in charge of the first evaluation of asylum applications. If they get a negative decision, or a lesser protection than the one expected, they can appeal in front of one civil tribunal out of the 26 presently competent on asylum and, in case of a second negative or unsatisfactory decision, they have a right to a second-level appeal at a Court of Appeal. In particular, I use the much discussed 'credibility issue' as a lens through which to observe how this notion is conceived of and employed by appeal judges in two different sites. I also show how this approach can help us understand the nature of this 'quasi-legal category' (Sweeney 2009) as a flexible device which is, at the same time, a core issue in the refugee status determination

B. Sorgoni $(\bowtie)$

Department of Culture, Politics and Society, University of Turin, Turin, Italy

e-mail: barbara.sorgoni@unito.it 
procedure, ${ }^{1}$ a sensitive category to handle with care, ${ }^{2}$ and an almost-empty shell that can be used for various purposes, stretching out far beyond the tribunals themselves. Such purposes can only be grasped when shifting the gaze from the mechanics of civil law as enacted inside specific local sites, towards national and supra-national migratory policies rooted in an entangling culture of indifference (Gill 2016). In their introduction to this volume, Gill and Good argue that the current attempt to consolidate a "Common European Asylum System" coincides with an unprecedented pressure on that same system, due to a drastic increase in the number of asylum seekers mostly fleeing from the war in the Middle East. They conclude by stressing how the 'harmonisation' of the European asylum system is still far from sight (see also European Commission 2016).

Against this context, to take a closer look at the way in which the asylum appeal procedure actually works in Italy is quite important, for three reasons. Firstly, because Italy is in the spot-light of European and international bodies governing migrations, being along with Greece (Cabot 2014), both a strategic check-point to guard the external frontiers of Europe, and one of the main doors for migrants to enter Europe. Secondly, because of some specificities of its asylum system-with two degrees of appeal on the merits (plus the possibility to challenge the legality of the decision before the Supreme Court), and with appeals being heard by civil courts instead of administrative ones. ${ }^{3}$ And finally, because it reveals an interestingly high degree of opacity, instability and variations of both decisional practices and underlying norms and assumptions, in a context which is as much vociferously discussed by the media as it is closed to the public and difficult to access for research purposes.

This chapter does not aim to be 'context-free', as in Bruno Latour's extremely engaging work on the making of law; on the contrary, and instead of trying 'to capture [...] the essence of law' (2010: x), I rather focus in detail on the civil tribunal of Bologna where I conducted research in 2013-2015, and relate it to that of Turin where I interviewed some magistrates in 2016. Despite Turin and Bologna being located some 300-kilometers apart, as the main towns of separate regions, the two were connected in relation to asylum: the Bologna TC was, at the time of my research, a subsection of the

\footnotetext{
${ }^{1}$ See Coffey (2003), Byrne (2007).

${ }^{2}$ As the many Manuals recently published under the CREDO project show: IARLJ (2013), UNHCR (2013), CREDO (2015).

${ }^{3}$ As I write, a highly contested reform is being discussed (D.L 13-17), whereby the procedure is reduced from three to two levels of decision: i.e. TC and first Tribunal appeal only.
} 
Turin one. ${ }^{4}$ My empirical data are drawn from participant observation of a tribunal determination, interviews with magistrates and lawyers, and a collective analysis of over 200 appeal decisions. By choosing to remain close to the local level, making space for ethnographic details, I do not intend to give up the possibility of showing the complex relations that tie specific legal procedures to a global understanding and (attempts at) governing asylum rights. On the contrary, I try to show how local practices would otherwise remain rather obscure if not related to the national and supra-national ideological and political frames that, paraphrasing Antonio Gramsci, De Genova has recently called 'the "European" Question' (2016). ${ }^{5}$ Conversely, by focusing on specific sites at different times, we can see how the repeated use of the notion of "refugee crisis" in Europe, and the 'politics of austerity, acutely affecting southern European countries in particular, coupled with border enforcement strategies that preemptively illegalise mobile people seeking asylum' (Tazzioli and De Genova 2016: 5), strongly impact on local-level decisional procedures of recognition or rejection.

\section{A Prequel}

In June 2011, the lawyer I had contacted for my research on Refugee Status Determination Procedure (RSDP) managed to persuade a judge at the Civil Division of the Bologna tribunal to let me participate as observer in a case regarding a denied asylum seeker from Pakistan. I had already learned that the first instance appeal takes place at the Civil Division of one of the many tribunals in the country, where appeals are set up as a camera di consiglio (chamber of council) which-as in other legal processes where privacy protection is privileged over the public nature of the proceedings - is not open to the public and, in the case of asylum, has a monocratic composition. Thus a magistrate, the claimant, their representing lawyer and a linguistic interpreter are the only actors involved. ${ }^{6}$ I therefore considered myself lucky

\footnotetext{
${ }^{4}$ While in 2010 ten TCs were operating in Italy, their number has presently risen to some 45 TCs, each composed of 4 members from the institutions involved (Prefecture, Police, Local authority and UNHCR): extended interviews are carried out by only one member, while final decisions are taken collectively.

${ }^{5}$ Or the need to redefine 'what is Europe', when the Schengen area of free mobility, at the core of European integration itself, seems to have failed.

${ }^{6}$ Asylum appellants usually cannot afford a lawyer: it is up to them to find those willing to give 'free' legal aid (patrocinio gratuito), whereby their fee is actually met by the State at a lower rate. As for the interpreter, things differ from one tribunal to another; in Bologna, they had then recourse to resident migrants who consented to translate for free or for a minimal reimbursement.
} 
to be allowed into a usually closed context, although I was not quite sure about what to expect. What I definitely did not anticipate, was how quickly it all would go.

On the morning of the hearing I met the lawyer at the tribunal, and she led me, the appellant and the interpreter to the judge's office: a small room simply furnished with a few shelves containing files and law books, a few chairs and a desk. On the walls and on the desk, some Catholic religious images and items were displayed. After introducing myself I was accommodated in a corner, while the appellant, his interpreter and his lawyer found seats at the desk, facing the judge. With both her posture and tone of voice, the judge made clear that she did not intend to waste any time, so while quickly flipping through the pages of the file she addressed the lawyer directly in Italian, questioning the nature of two new documents she found in the file. Since the interpreter had started to translate, the judge stopped him, explaining he should only translate when told to do so, and asked him first to confirm that he was the linguistic interpreter 'from Pakistani language'.

The lawyer explained to the judge that the two new documents were, respectively, a medical certificate from the hospital attesting to the injuries suffered by the appellant's relatives, and the police report following the assault on the appellant's relatives by a group of neighbours. ${ }^{7}$ She then added:

the scope of the appeal is to eliminate any doubt. The TC expressed doubts about this case in relation to a lack of documentation concerning medical certificates and police reports, which we now produce. But the TC did not provide clear reasons for the final denial: this fact alone is, for many judges, a reason to appeal. ${ }^{8}$

The judge finally told the interpreter to translate what the lawyer had affirmed, and to ask if the appellant wished to add anything. He replied with a plea; 'to the Italian government, that I may be allowed to remain in Italy at

\footnotetext{
${ }^{7}$ I knew from the lawyer's file that behind the assault was an attempt to grab the land of the appellant's patrilineage following the death of his father and brother; yet during the appeal there was no reference to those reasons, nor to documented land disputes in rural Pakistan, where the police are often unable or unwilling to offer protection to the party harmed, or complicit with the offenders, as Refworld Report attested. See: http://www.refworld.org/docid/5072ca722.html.

${ }^{8}$ The lawyer was referring to the fact that, in denying all three types of protection-refugee status, subsidiary protection, and humanitarian protection (a national protection granted under Legislative Decree 25 July 1998 , no. 286 , art. 5 c. 6) - the TC omitted to explain the reasons for each individual denial.
} 
least until the situation in Pakistan is solved. I am the only one left to support my large family and if I go back my life is at risk.' It was at this point of a very short hearing that, in a few seconds, everything changed: from the tone of voice of the judge and the look in her eyes, to the colour of the lawyer's face. The judge quickly re-read her notes through, asking the interpreter to translate sentence by sentence for the appellant to agree and sign the minutes. It thus appeared she had annotated 'economic support'; when questioned by the lawyer on this point, she conceded: 'I may have added "economic" to the word "support" myself, but I do not really think this is a matter for interpretation, do you?'. She handed over the minutes for signature, and murmuring the ritual sentence-'I shall reserve my decision' ${ }^{\text {' }}$-she quickly dismissed us all. Being my first time, I did not immediately catch why the lawyer was literally trembling with fury, thinking this was due to the rapidity of the procedure and the absence of a real interview. But, as she explained when she burst out in front of her client, she already knew the outcome would be rejection because he had wrongly suggested material difficulties; 'and he shouldn't have! I had explained this very clearly in my office only half an hour before. He said he understood! He should not have ever mentioned economic reasons. He should have stuck to the truth!'.

What struck me then about what I had witnessed was the apparent ease with which a person who is endowed with the authority can decide in such a short time (about 20 minutes altogether) on issues relating to the life and death of another person. But over time, I came to realise that many more things characterised this particular type of legal encounter. For instance, it was possible to apprehend there how inaccurate the previous interview in front of the TC had been, where no motivation for rejection was offered, and a negative decision was based merely on 'scepticism' due to a lack of appropriate documentation. ${ }^{10}$ It also revealed that no real second interview may take place even though the judge herself had convoked the appellant; that complex social and cultural realties are reduced to transparent facts that need no further investigation, rather than being recognised truly as 'matters of interpretation' (Gibb and Good 2013); and that additional documents could be totally neglected, despite the whole appeal revolving around them. Finally, it showed how-vis-à-vis a very poor knowledge of the appellant's country of origin (as signaled by the reference to a 'Pakistani language'), and

\footnotetext{
${ }^{9}$ With this closure sentence the judge defers the decision to a later moment.

${ }^{10}$ Notwithstanding the fact that in RSDP 'the duty to ascertain and evaluate all the relevant facts is shared between the applicant and the examiner' (UNHCR 1979): a principle confirmed in Italy by the Supreme Court (Cass. S.U. 17/11/2008, no. 27310).
} 
no further enquiry into the nature of violence connected to land disputesthe decision could be based on one single 'wrong' word.

\section{At the Tribunal}

In 2013, two years after this experience, I was involved in the cocoordination of research to be carried out at the Bologna tribunal. The president of a newly born association to which I belong ${ }^{11}$ obtained permission to conduct research on the files concerning asylum appeal determinations taken by that tribunal. During an introductory meeting, the president of the Civil Division — competent, among other issues, on asylum-explained how the system worked: the Division received and temporarily stored files about single appellants, containing all the documents assembled up to that stage. ${ }^{12}$ Those documents were received only as print-outs, so they were extremely vulnerable: there was only one copy for each file, and if they migrated to the Court of Appeal, they might not come back or might be dismembered. All the files that did come back (and those which never migrated) should then be sent to the archive, located in a different building. But the files' careers didn't stop there. Once in the archive, the files underwent a new transformation, becoming nearly invisible: they still existed, but could not be easily retrieved. This happened (indeed, at that time, across the whole country) because asylum cases were not labelled under a single specific code but rather drowned in the vast sea of files from the Home Office which, as the president stressed, 'literally encompasses everything'. As the president went on with her explanation, another quite peculiar obstacle became clear: namely, that our admission to the archive for study purposes would be 'out of the question', since 'the archivist in charge doesn't tolerate any other presence there, besides herself and a few clerks.'.13

\footnotetext{
${ }^{11}$ Founded in 2013, Asilo in Europa brings together experts on asylum issues from different countries, in order to create a network to share knowledge and praxis, and to offer comparative and updated information of different types across Europe.

${ }^{12}$ These comprised: the first request-form filled at a police headquarter (C3); the transcript of the TC's extended interview; its final decision; its notification to the claimant; any documentation provided by the claimant at the first hearing; the appeal motivation from the assisting lawyer; any documentation added at the appeal stage; transcript of the eventual appeal hearing; the judge's decision; its notification to the appellant.

${ }^{13}$ Meeting at the Bologna tribunal, 15th of March 2013. On archival relevance for anthropological studies and the materiality of paper documents also in asylum, see Basu and De Jong (2016), Cabot (2012), Hull (2012), Latour (2010), Sorgoni and Viazzo (2010), Stoler (2009).
} 
In sum, if we add together the fact that asylum files exist only as onecopy print-outs, that they might migrate and get lost or damaged on the way, and that they were not catalogued as a homogeneous category, we easily understand the recent admission of Prefect Trovato at his hearing in front of a Parliamentary commission monitoring the influx of migrants. "We possess total national data on the number of accepted or rejected appeal claims', he explained, adding that in order to get separated statistics on single judiciary bodies, 'we should go and look from tribunal to tribunal' (Parliamentary Hearing 2015: 13, my translation). This admission renders Asilo in Europa's research (2015) extremely valuable, being so far the only existing quali-quantitative study of first instance asylum appeals (in a specific tribunal) in Italy.

Over a period of about a year, members of the association studied and classified some 233 appeal files relating to decisions from 2011 to 2013. On the one hand this time span was compulsory, since only recent files were still temporarily stored inside the tribunal while waiting to be sent to the main archive. But on the other hand, the period proved strategic, giving us the additional possibility of verifying whether the unrest in Tunisia, the so called 'Arab spring', and the Libyan war in 2011-2012-which had resulted in a consistent increase in the number of migrants to Italy, and in ad hoc reception policies labelled ENA (North African Emergency)—significantly impacted on the decisions and, eventually, in what way. I come back to this latter issue below; here I want first to give some numerical data about asylum appeals in Bologna, as they emerged from our research.

To classify the files, we selected some relevant criteria: age, sex and country of origin of the appellant; length of the entire determination procedure; if appealing from an open centre or a CIE (Centre for Identification and Expulsion, i.e., administrative detention); if falling under the ENA label; the percentage of procedurally-based decisions vis-à-vis decisions on the merits; and the completeness of the file. About the latter point, it is important to note that out of 233 files, only 22 were complete in the sense defined earlier (see Footnote 12). Also, out of 233 files, 21 contained no trace of any decision while in 41 cases the decision was founded solely on procedural grounds, which left us with 171 files to analyse thoroughly. Out of 171 files, $110(64 \%)$ ended with a rejection of the appeal, while in 61 cases $(36 \%)$ the judge decided to allow the appeal: in these cases, only one person obtained refugee status, with 22 obtaining subsidiary protection, and 38 (over 62\%) a one-year humanitarian protection.

Turning now to the so-called ENA, and in order to understand its impact on appeal decisions in Bologna, we need to switch momentarily from the 
determination procedure to the reception system, since what made that phenomenon a publicly recognised political débâcle was not only the substantial increase in the number of migrants (from less than 5000 in 2010, to over 62,000 in 2011), but also the Government decision to assign their reception to the Civil Protection Corps, usually in charge of natural disasters. ${ }^{14}$ A new and temporary reception system was thus abruptly set in place with full power, running parallel to (and at times conflicting with) the already existing and tested one. To cut a long and disastrous story short, ${ }^{15}$ it is important to know that the logic behind the reception of those migrants consisted mainly in separating Tunisians from 'Libyans', both in spatial and procedural terms. The former were initially given six-months leave and de facto allowed to cross the national border (mostly to France), and later forcibly repatriated according to the Italy-Tunisia Treaty hastily signed in March 2011; the latter were distributed across the country in new 'ENA centres' where they were to wait until their claim for protection was processed (which turned out to take about two years). This second group was almost entirely composed of sub-Saharan Africans who had been living and working - many already for years - in Libya when the war started, and who fled the country across the Mediterranean. Thus, many of those who applied in the first year received a denial, usually on the grounds that they could safely 'go back' to their respective 'real' countries of origin. In fact in 2011 , over $76 \%$ of asylum applications (out of 37,350 total applications) concerned persons from Africa-mostly from Nigeria, Ghana, Mali (coming from Libya), and Tunisia. At the end of that year, 65\% of Nigerians, $76 \%$ of Ghanaians and $82 \%$ of Malians respectively, were denied any type of protection (Ministero dell'Interno 2016b).

What the Italian Government had not anticipated was the clogging of both the TCs - which collapsed under the pressure of such high numbers-and the tribunals, which started to receive appeals from those denied. This further resulted in an unforeseen extension of the declared 'state of emergency', and consequently of the life (and costs) of the new and supposedly temporary ENA hosting centres. After almost two years, the Home Office issued a circular ${ }^{16}$ suggesting the TCs granted humanitarian protection to all those known as

\footnotetext{
${ }^{14}$ For detailed descriptions and critical assessments of the ENA process see Marchetti (2012), Bracci (2012), Olivieri (2011) on local and national aspects respectively.

${ }^{15}$ During a public conference (Bologna, 12 April 2013) on the Civil Protection management, Prefect Compagnucci acknowledged that in the sacred chambers of power we soon realised this had been a mistake, yet we did not change it. This resulted in far too lengthy procedures at an enormous cost'.

${ }^{16}$ Home Office, Circular no. 400/C/2012, 31 October 2012, Overcoming North African Emergency.
} 
'ENA asylum-seekers', a solution which eventually afforded the opportunity to put a political end to the emergency itself, and finally close the centres.

The present relevance of this story is that it also impacted directly on the tribunal's decisions. As shown above, before the 2012 government disposition, TCs all over Italy tended to deny any protection to sub-Saharan Africans fleeing the war in Libya, on the ground that they could go back to their 'country of origin'; many of them appealed against the denial. A founding principle of democracy, the separation of powers is particularly relevant in human rights issues, and a fundamental principle according to EU law. ${ }^{17}$ As Sicakkan (2008: 218) proved in his research on asylum systems in 17 European countries, 'institutional decision-making frames where central authorities act as the first instance and legal courts as appeal instance' are associated with procedures which are fairer with regard to applicants' rights. Thus, in the ENA situation, the fact that the decisions' outcome at first (state) instance switched from flat denial to humanitarian protection after the 2012 ministerial circular, may come as no surprise. ${ }^{18}$ But in a 'separate system', appeal courts are then expected to decide in relation to individual cases independently from the administrative instance's previous decision. Indeed, the main purpose of a tribunal system is to allow individuals to appeal to an independent judicial body against a negative decision from the government. It should therefore be a surprise that, among the 37 appeal files that we analysed relating to men from Ghana fleeing from Libya, those seven who appealed before the 2012 government circular were all rejected, while 26 out of the 30 who appealed after the circular had the first negative decision turned into humanitarian protection.

This example seems to point to the fact that the separation of the administration and the judiciary, while existing in theory, may blur in the actual making of the law, especially under certain circumstances. In this specific event, we may reasonably think that such circumstances had mostly to do with the sudden and unexpectedly high increase in the number of asylum claimants in the space of a few months. While this is partly the case, in the last section I argue that there are more reasons of a diversified political and cultural nature behind all this. Or, to phrase it differently, the continual resort to notions such as "refugee crisis" or "migrants emergency" is productive of specific policies, whereby human rights, embedded in a unique

\footnotetext{
${ }^{17}$ Art. 47 Treaty of Nice.

${ }^{18}$ Indeed in 2012, when the Home Office inverted its policy, $80 \%$ of Nigerians and $89 \%$ of Ghanaians received Humanitarian Protection, while 78\% of Malians got subsidiary protection (Ministero dell'Interno 2016b).
} 
relationship between an individual claim and a specific hosting State, are instead managed as political issues of border control between States, mediated by EU and international agreements (Hansen and Stepputat 2005; Sorgoni 2011, see also Gill and Good's Introduction to this volume). The ENA situation also uncovers a mechanism based on collective decisions rather than on the careful evaluation of individual stories, which translates into similar stories resulting in divergent outcomes. For instance, in seven cases the judge accorded humanitarian protection on the ground that 'the appellant can be included among those addressed by the 30.10.2012 circular' (Asilo in Europa 2015: 12, my translation) independently from their personal story, while in 16 decisions the reason for allowing the appeal referred to 'a dignified affective and working life in Libya' which had been destroyed by war (ibid.). No mention was made about Ghana as a safe country of origin where the appellant could 'go back', or that the appellant had first left for 'mere personal and economic reasons', as stated instead in all the negative decisions issued before the 2012 circular. Again, rather than an example of arbitrary interpretation of human rights laws, this shows asylum as governed by more or less visible migratory politics of containment and control.

\section{So, What Does Credibility Mean?}

Credibility in refugee law has been a matter of concern at least since the first steps towards the formulation of a common asylum policy in the late nineties. UNHCR (1998) stressed the importance of oral testimony as evidence, especially when, as is often the case with asylum, claimants do not possess other types of material evidence attesting to their identity and their story of persecution. Given precisely this peculiarity of international protection law, an evaluation of the credibility of claimants' narratives has always been an issue (Coffey 2003). The subsequent Qualification Directive (2004/83/EC) consequently allows decision makers to evaluate the coherence and plausibility of the asylum seekers' oral testimony, and their general credibility, when other material evidence is unavailable ${ }^{19}$ (see Craig and Zwaan, this volume, for an introduction to this Directive).

But the credibility issue in asylum hearings has become the object of intense scrutiny in recent times - as the CREDO project and its publications

\footnotetext{
${ }^{19}$ The Directive 2011/95/EU (transposed in Italy in January 2014) replaced the 2004 QD introducing no amendments on this point.
} 
testify - with the specific aim of setting judicial criteria and standards. All these Manuals highlight how the effort is particularly needed in the face of 'the unique nature of decision-making in this arcane and highly specialised area of law' (IARLJ 2013: 11), where a core legal category in the common European procedure is also one which is 'understood differently across national asylum systems' (CREDO 2015), partly because the word itself is used with different meanings in each national language. In a somewhat circular logic, the effect (heterogeneity being the necessary outcome of the decision to employ a notion which is historical and contextual, relating as it does to philosophical and cultural understandings of concepts like truth, reality, and person) is turned into a cause (different national understandings of credibility introduce arbitrariness and dis-homogeneity in an otherwise common system), therefore the notion needs to be standardised. Recent attempts to define it more clearly, intend to try and reduce such ambiguities: "What is needed therefore, in linguistic terms, is "contextual disambiguation" to ensure the concept of "credibility" is used correctly' (IARLJ 2013: 12). This, it is proposed, may be obtained by avoiding 'loose' definitions of the term ('the credibility of everything related to the claim'), concentrating rather on the 'claimant's past and present factual background' (ibid., my emphasis). The material facts in the claimant's story must be found internally and externally consistent (i.e., assessing discrepancies within the evidence presented by the claimant, or with evidence provided by experts or Country of Origin Information [COI] Reports). The decisionmaker should take into consideration the totality of the findings of fact (and not found the decision on single or marginal ones); any type of evidence produced should be carefully weighted (including documentary evidence acquired by the decision-maker); and relevant COI should be obtained and evaluated.

It seems that the above attempt at disambiguation consists mainly in narrowing the meaning of the notion, while at the same time limiting its weight: credibility is therefore explicitly linked to the facts narrated rather than to the individual per se; and it should be measured in relation to both the totality of the facts, and also other types of evidence (both material and non-material). By stressing the need to reduce the relative weight of 'credibility' in RSDP, such recent efforts also indirectly signal the increased importance the notion had gained, vis-à-vis other types of evidence (Sorgoni, under review). The research at the Bologna tribunal confirmed the central role played by credibility: in 171 files, 76 (44\%) were rejected becauseamong other things - either the applicant or the story were declared 'not credible' (and also 'not plausible', or 'inconsistent'); in 11 cases (14\%) the lack of credibility figured as the only ground for rejection, often without 
any further explanation (Asilo in Europa 2015). In a national legal context in which the adherence to a common system was at the time still young (Cherubini 2015), the European directives only just transposed, and a COI system - which could counter-balance decisions based solely on the narrative's evaluation-virtually non-existent, the use of the credibility notion in those years was so pervasive that the category came to mean anything, and nothing.

Again, the case of a man from Pakistan of Shiite orientation living in a Sunni majority area can help illustrate this. The TC had already denied him the right to any protection on the ground that the facts narrated appeared 'poorly credible' because, after having been abducted and tortured by a group of Sunnis, he did not report to the police; his story was 'contradictory' since he had mentioned the need to support his family; and he himself appeared not credible because he was not able to state the consequences he would face if returned, having merely declared: 'I don't know what could happen to me'. ${ }^{20}$ Five months later, at the appeal, he produced a medical certificate attesting to the injuries suffered by his son during a similar assault, and the related report to the local police. While no mention of this documentation was made by the judge, he likewise found the appellant not credible, mainly because he presented no proof of his Shiite faith, nor any information 'about his sustenance while in Italy'. ${ }^{21}$ When weighted against the suggestions put forward by the above Manuals, the application of the credibility notion in this decision is definitely very loose, based as it is on marginal or totally irrelevant facts, without the acquisition on the part of the judge of documentary evidence or COI, and with the dismissal of primary documents produced by the appellant.

But credibility can reach a 'ground zero' level, when it is reduced to an empty wrapper. This is the case of a young woman and single mother from Senegal who was denied international protection without having been interviewed: since she could not attend the first screening, the TC assumed she was not genuinely motivated. During the appeal hearing, she explained to the judge that she had obtained an official remittal of the first screening, but had missed its re-scheduling because they had changed the location. Despite the fact that no other question was raised, in the eyes of the judge the

\footnotetext{
${ }^{20}$ The TC interpreted the sentence literally, suggesting that if the applicant didn't even know what he risked, there was clearly no real danger in going back. It goes without saying that a non-literal translation could convey a totally different meaning, as in the semantic form of preterition.

${ }^{21}$ Notwithstanding the fact that the 'sustenance' issue has some relevance for economic migrations, but has none in relation to RSDP.
} 
appellant's behaviour undermined her credibility since she failed to attend the interviews 'without adducing any justification' and she 'reported nothing in relation to her way of sustenance in Italy' so that 'in sum, her whole story appears inconsistent, vague, without any possible ascertainment'. The problem, in this case, lies in the fact that there was no story to evaluate, neither at the first hearing (which never took place), nor at the appeal stage where only irrelevant or inappropriate questions were asked.

A loose evaluation of credibility can also take other forms, as in the case of a young man from Iraq. His story was in principle sadly simple: it could have been easily classified as an 'instrumental later claim' to avoid deportation, from an 'illegal migrant' who had been working irregularly in Italy for over 9 years. When his irregular position was accidentally detected by the police, he was taken to a CIE with a repatriation order, and applied for asylum. He was interviewed by the TC a month later and, upon denial, he appealed: despite the hearing being scheduled only two months later, this was a non-suspensive appeal which never took place, since he had been deported. If the preceding story was a zero-level credibility instance-the non-credibility of the story grounded on an absent story-in this case we find an apparently unreasonable excess in the recourse to the credibility notion. In face of a lack of valid residence permits and a regular job, an asylum claim put forward to avoid deportation is considered, by definition, not genuine and leads to rejection. So why did the TC feel the need to refer to the (non)credibility of the story in order to justify its negative decision? Indeed, by merely evaluating the testimony's credibility, the TC should come to an opposite decision. For what is incoherent about an illiterate Iraqi Kurd raised by his mother in Syria until her premature death, who then worked in Libya before moving to Italy? And why is it implausible that he could not name current political parties, the outcome of the last elections, and a very famous museum, all in relation to a country he fled under the bombs, at the age of 6 ?

\section{Beyond Credibility}

The research I have presented shows a very loose and unmotivated, excessive recourse to the notion of credibility to ground negative determinations, so that to a certain extent a better knowledge and a more careful employment of the suggestions put forward by the many existing manuals on asylum determination, could have limited the sense of arbitrary unfairness one gets from reading those files. 
Yet, I am not sure that, by switching from the credibility of the applicant to that of the application-the credibility of the person $v$ s that of the account (CREDO 2015) - the (inherent) ambiguity of the notion vanishes. What appears in the CREDO manuals as a move towards maximising objectivity, in fact obscures other aspects that cannot be neglected. One is the decisionmakers' own subjectivity, the processes at work in their minds in the specific setting of asylum hearings (Johnson 2013), as well as their 'personal theories of "truth" and "risk", which those recent manuals acknowledge (suggesting they should be minimised, while leaving aside how and if this is altogether possible); another is the 'need to understand subtle cultural, gender, demeanour and linguistic issues' (IARLJ 2013: 19), a task that cannot be improvised and proves extremely difficult to address; and finally the inter-subjective nature of the claimants' narrative, produced with the active participation of many subjects beside the claimant him/herself, through an elaborate en-textualisation process (see Spotti, Gibb, this volume) which ex post attributes to asylum seekers, as 'their own words', what is in fact a stratified texture woven by many hands at various stages of a long procedure, in different institutional settings (see Danstrøm and Whyte, this volume). ${ }^{22}$ Therefore, while a loose use of the notion could and should be avoided, I believe that a residual and irreducible trace of ambiguity will necessarily remain.

But my intention here is not to offer ad hoc solutions to make the existing asylum system fairer to those 'happy few' who land alive at the external frontiers of Europe, thus supporting the positivist illusion that finding yet more technicalities, or refining existing ones, will eventually render the screening of human beings 'objective'. ${ }^{23}$ While acknowledging that legal processes are (necessarily?) intrinsically positivist, this recognition does not render the procedure 'objective': rejected claimants may not be 'objectively undeserving', but appear to be so after having been processed by a long, non-homogeneous and fragmented procedure. A procedure in which hidden cultural assumptions 'typically permeate the mind-set of lawyers' and judges (Grillo 2016; Ballard 2010), and which is embedded in (macro)political orientations. A fair recognition of the aspiration of a multitude to a digni-

\footnotetext{
${ }^{22}$ These aspects have long been addressed in anthropological critique of the asylum system; see among others: Blommaert (2001, 2009), Good (2007), Gibb and Good (2014), Jacquemet (2005), Maryns (2006), Cabot (2011) on Greece, Sbriccoli and Jacoviello (2011), Sorgoni (2013) on Italy.

${ }^{23}$ See Campbell (2013) on supposedly objective technicalities in UK; Fassin and Kobelinsky (2012) on deontological ethics of appeal judges in France. On a personal level, the general system presupposes a belief in the right to select between 'the drowned and the saved' (Levi 1986): a moral position I do not wish to embrace.
} 
fied and safe life does not depend on correcting some faults in the asylum system, as if the system itself existed in a vacuum, independent and detached from those global migratory politics and rhetorics in which, on the contrary, it is radically embedded. Such politics and rhetorics magnify the commitment to homogeneous and objective determinations, while obfuscating how a few fair decisions are predicated upon the potentially extremely unfair rejection and exclusion of the majority, and their confinement in the global south, or in some new no man's land as the hotspots in Greece and Italy, where most migrants are summarily labelled as 'economic migrants', i.e. illegal migrants with no right to even begin to access the asylum procedure. ${ }^{24}$

In the same vein, the findings discussed here are not intended as a way to judge the judges: while we can acknowledge the many failings of the determination system as practiced at the tribunal in 2011 in Bologna, ${ }^{25}$ it would be unfair and definitely myopic to stop there. Those faults had various causes: the absence of a proper COI system which could provide updated information on the socio-political situation of the area of origin; the workload of judges not specifically nor solely dedicated to asylum issues; their reduced number vis-à-vis that of appeals; their (often) poor preparation in international protection and EU law; and their poor familiarity with playing an active role and sharing the burden of the proof. ${ }^{26}$ But we should look also beyond the tribunal's rooms, the imperfections of the system, or the credibility issue itself.

And if we look at asylum recognition rates in Italy from 2008 to 2015, we discover that denials peaked twice: in 2011 and 2015 (Anci et al. 2016: 103). The first is the period addressed with the former research in Bologna, the second coincides with my current research in Turin. There are significant differences between the two contexts: in Turin judges now share a database on determinations, classified by country and type, that allows them to compare similar cases to avoid divergent outcomes; they circulate information from reliable and updated COI websites; an interpreter is present and paid by the tribunal. They are also aware of the traps of the credibility notion especially for 'civil law judges, who are more familiar with documents than

\footnotetext{
${ }^{24}$ As a response to the "refugee crisis", the European Agenda on Migration adopted on 31st May 2015 (European Commission 2015) introduced new border points in Greece and Italy, denominated hotspots, where Europol, Easo and Frontex officials support national ones to ensure quicker identification and fingerprinting procedures. So far, this is probably the most disputed issue of the Agenda (Amnesty International 2016).

${ }^{25}$ Asilo in Europa Report (2015) offers some recommendations in that sense.

${ }^{26}$ A magistrate to the author, Turin, November 2016.
} 
with life stories'. ${ }^{27}$ Most of all, they are acutely critical about their insufficient numbers and 'the loneliness of the asylum judge', especially since asylum is but one among their many duties. And they relate to their insufficient number the fact that 'now we don't interview [the appellants] any more'. ${ }^{28}$

In 2011, for the first time, the European myth of safe external borders crashed; again in 2015 all the securitisation measures adopted proved useless in face of the Syrian civil war. In both cases the EU, or single European states, reacted by signing 'treaties' with non-European states in order to block the migrants before they even reached its external borders, while the rhetoric of the 'refugee crises' became a media and political leitmotiv and the term 'crisis' itself self-explanatory (Roitman 2014; De Genova and Tazzioli 2016; Knight and Stewart 2016). At a national level, on both occasions governmental circulars pushed for either collective decisions (as with ENA in 2012), or cursory ones (as with the 19.6.2015 circular pretending each TC evaluate at least 16 claims per day $\left.{ }^{29}\right)$, justifying such extraordinary measures with reference to the sudden increase of migrants. And yet in 2015, 154,000 migrants entered Italy (while in 2014 there were 170,000), out of which 84,000 applied for asylum (as opposed to 60,000 in 2014). Rather than supporting the fabricated sense of invasion, the numbers expose a long lasting political choice and self-representation of Italy as a transit country, an accidental destination to be dealt with through laisser-passer formal and informal policies (Ciabarri 2016; Kersh and Mishtal 2016; Tuckett 2015, 2016) that periodically reiterate the 'migrants emergency' issue as a sudden and unexpected event that threatens national cultural and religious identity (Giordano 2014). This is a 'politics of scarcity' (Vacchiano 2011: 194) where the collapse of the system is not due to an excess of migrants, but to a deliberate adoption of ever-temporary measures, and a systematic avoidance of adopting serious policies of recognition, reception and inclusion. Such policies would include, among other things, a strengthening of the national asylum system, both in qualitative and quantitative terms. In the absence of this, the different responses at Bologna and Turin are but two sides of the same coin, and a fairer asylum system — albeit morally due-is but a band-aid solution fed by the same 'culture of denial' (Souter 2011), and the same self-fulfilling prophecy that 'they' are not here to stay. The day after the release of an official EC video on the effective sealing of borders, ${ }^{30}$ a

\footnotetext{
${ }^{27}$ A magistrate to the author, Turin, December 2016.

${ }^{28}$ Ibid.

${ }^{29}$ Such circulars are not public but this one was mentioned in an official publication: (Ministero dell'Interno 2016a: 34).

${ }^{30}$ 2016: the year the EU took robust action to control migration flows https://youtu.be/ EYO0z2Tnr2A?list=PLXPWZG37uPbOH-i8kqpPoxGzLLDt9i1Sd [14 December 2016].
} 
judge commented: 'why don't they simply say that we cannot afford to protect human rights, so that we just quit?'.

\section{References}

Amnesty International. (2016). Hotspot Italia. Come le politiche dell'Unione Europea portano a violazioni dei diritti di rifugiati e migrant. Available at: https://www. amnesty.it/rapporto-hotspot-italia/.

Anci, Caritas italiana, Cittalia, Fondazione Migrantes, SPRAR, UNHCR. (2016). Rapporto sulla protezione internazionale in Italia 2016. See: www.viedifuga.org.

Asilo in Europa. (2015). Ricerca sui provvedimenti del Tribunale di Bologna in materia di protezione internazionale. Available at: http://asiloineuropa.blogspot. com/2016/01/ricerca-sulle-decisioni-del-tribunale.html.

Ballard, R. (2010). Applied Anthropology: A Viable Career Path in Contemporary Britain? EASA Conference Workshop on Public Anthropology for a World in Crisis, Maynooth, Republic of Ireland, August 2010. Paper Available at: http:// www.casas.org.uk/papers/pdfpapers/appliedanth.pdf.

Basu, P., \& De Jong, F. (2016). Utopian Archives, Decolonial Affordances [Introduction to Special Issue]. Social Anthropology/Anthropologie Sociale, 24(1), 5-19.

Blommaert, J. (2001). Investigating Narrative Inequality: African Asylum Seekers' Stories in Belgium. Discourse and Society, 12(4), 413-449.

Blommaert, J. (2009). Language, Asylum, and the National Order. Current Anthropology, 50(4), 415-441.

Bracci, F. (Ed.). (2012). Emergenza Nord Africa. I percorsi di accoglienza diffusa. Analisi e monitoraggio del sistema. Pisa: Pisa University Press.

Byrne, R. (2007). Assessing Testimonial Evidence in Asylum Proceedings: Guiding Standards from the International Criminal Tribunals. International Journal of Refugee Law, 19, 609-638.

Cabot, H. (2011). Rendere un 'rifugiato' riconoscibile. Performance narrazione e intestualizzazione in una Ong ateniese. Lares, 77(1), 101-122.

Cabot, H. (2012). The Governance of Things: Documenting Limbo in the Greek Asylum Procedure. PoLAR. Political and Legal Anthropology Review, 35(1), $11-29$.

Cabot, H. (2014). On the Doorstep of Europe: Asylum and Citizenship in Greece. Philadelphia: University of Pennsylvania Press.

Campbell, J. (2013). Language Analysis in the United Kingdom's Refugee Status Determination System: Seeing Through Policy Claims About 'Expert Knowledge'. Ethnic and Racial Studies, 36(4), 670-690.

Cherubini, F. (2015). Asylum Law in the European Union. London and New York: Routledge.

Ciabarri, L. (Ed.). (2016). I rifugiati e l'Europa. Milano: Raffaello Cortina.

Coffey, G. (2003). The Credibility of Credibility Evidence at the Refugee Review Tribunal. International Journal of Refugee Law, 15(3), 377-417. 
CREDO. (2015). Credibility Assessment in Asylum Procedures. Expert Roundtable. Budapest, Hungary, 14-15 January 2015. Available at: http://helsinki.hu/ wp-content/uploads/CREDO-training-manual-2nd-volume-online-final.pdf.

De Genova, N. (2016). The 'European' Question: Migration, Race, and PostColoniality in 'Europe'. In A. Amelina, K. Horvath, \& B. Meeus (Eds.), An Anthology of Migration and Social Transformation: European Perspectives (pp. 343356). New York: IMISCOE.

De Genova, N., \& Tazzioli, M. (Eds.). (2016). Europe/Crisis: New Keywords of 'the Crisis' in and of 'Europe'. Zone Books online. http://nearfuturesonline.org/ europecrisis-new-keywords-of-crisis-in-and-of-europe/.

European Commission. (2015). A European Agenda on Migration. Brussels 13 May 2015. See: http://ec.europa.eu/anti-trafficking/sites/antitrafficking/files/ communication_on_the_european_agenda_on_migration_en.pdf.

European Commission. (2016). Press Release: Commission Presents Options for Reforming the CEAS and Developing Safe and Legal Pathways to Europe. Brussels, 6 April 2016. Available at: http://europa.eu/rapid/press-release_IP-16-1246_en.htm.

Fassin, D., \& Kobelinsky, C. (2012). Comment on juge l'asile: l'institution comme agent moral. Revue française de sociologie, 53(4), 657-688.

Gibb, R., \& Good, A. (2013). Do the Facts Speak for Themselves? Country of Origin Information in French and British Refugee Status Determination Procedures. International Journal of Refugee Law, 25(2), 291-322.

Gibb, R., \& Good, A. (2014). Interpretation, Translation and Intercultural Communication in Refugee Status Determination Procedures in the UK and France. Language and Intercultural Communication, 14(3), 385-399.

Gill, N. (2016). Nothing Personal? Geographies of Governing and Activism in the British Asylum System. Oxford: Wiley-Blackwell.

Giordano, C. (2014). Migrants in Translation. Caring and the Logics of Difference in Contemporary Italy. Berkeley: University of California Press.

Good, A. (2007). Anthropology and Expertise in the Asylum Courts. Abingdon and New York: Routledge and Cavendish.

Grillo, R. (2016). Anthropologists Engaged with the Law (and Lawyers). Antropologia Pubblica, 2(2), 3-24. Available at: https://riviste-clueb.online/index. php/anpub/index.

Hansen, T. B., \& Stepputat, F. (Eds.). (2005). Sovereign Bodies. Citizens, Migrants and States in the Post-colonial World. Princeton and Oxford: Princeton University Press.

Hull, M. (2012). Documents and Bureaucracy. Annual Review of Anthropology, 41, 251-267.

IARLJ. (2013). Assessment of Credibility in Refugee and Subsidiary Protection Claims Under the EU Qualification Directive. Available at: www.iarlj.org/general/images/ stories/Credo/Credo_Paper_18Apr2013.pdf.

Jacquemet, M. (2005). The Registration Interview. Restricting Refugees' Narrative Performance. In A. de Fina \& M. Baynham (Eds.), Dislocations/Relocations. Narratives of Displacement (pp. 197-220). Manchester and Northampton: St. Jerome Publishing. 
Johnson, T. A. M. (2013). Reading the Stranger of Asylum Law: Legacies of Communication and Ethics. Feminist Legal Studies, 21, 119-139.

Kersch, A., \& Mishtal, J. (2016). Asylum in Crisis: Migrant Policy, Entrapment and the Role of NGOs in Siracusa, Italy. Refugee Survey Quarterly, 35, 97-121.

Knight, D. M., \& Stewart, C. (2016). Ethnographies of Austerity: Temporality, Crisis and Affect in Southern Europe. History and Anthropology, 27(1), 1-18.

Latour, B. (2010). The Making of Law. An Ethnography of the Conseil d'Etat. Cambridge and Malden: Polity Press.

Levi, P. (1986). I sommersi e i salvati. Torino: Einaudi.

Marchetti, C. (2012, December). Framing Emergency. Italian Response to 2011 (Forced) Migrations from Tunisia and Libya. Paper presented at the RSC 30th Anniversary Conference: Understanding Global Refugee Policy, Oxford, 6-7.

Maryns, K. (2006). The Asylum Speaker. Language in the Belgian Asylum Procedure. Manchester and Northampton: St. Jerome Publishing.

Ministero dell'Interno. (2016a). Piano Accoglienza 2016. Tavolo di Coordinamento Nazionale. Available at: http://www.vita.it/attachment/ d601c9b0-b314-46ba-b708-d4341546c2d9/.

Ministero dell'Interno. (2016b). Quaderno Statistico 1990-2015, http://viedifuga.org/wp-content/uploads/2016/05/Quaderno_statistico_1990-2015_ INTERNO_4_2016.pdf.

Olivieri, M. S. (2011). L'accoglienza frantumata sotto il peso dell 'emergenza'. In Lunaria (Ed.), Cronache di ordinario razzismo. Secondo libro bianco sul razzismo in Italia (pp. 35-44). Roma: Edizioni dell'Asino.

Parliamentary Hearing. (2015). XVII Legislatura, Comitato parlamentare di controllo sull'attuazione dell'Accordo di Schengen, Seduta no. 31, http://documenti.camera.it/leg17/resoconti/commissioni/stenografici/html/30/indag/c30_ flussi/2015/06/04/indice_stenografico.0031.html\#stenograficoCommissione. tit00020.int00020.

Roitman, J. (2014). Anti-Crisis. Durham: Duke University Press.

Sbriccoli, T., \& Jacoviello, S. (2011). The Case of S: Elaborating the 'Right' Narrative to Fit Normative/Political Expectations in Asylum Procedures in Italy. In L. Holden (Ed.), Cultural Expertise and Litigation: Patterns, Conflicts, Narratives (pp. 172-194). London: Routledge.

Sicakkan, H. G. (2008). Political Asylum and Sovereignty-Sharing in Europe. Government and Opposition, 43(2), 206-229.

Sorgoni, B. (2011). Pratiche ordinarie per presenze straordinarie. Accoglienza, controllo e soggettività nei centri per richiedenti asilo in Europa. Lares, 77(1), $15-33$.

Sorgoni, B. (2013). Chiedere asilo. Racconti, traduzioni, trascrizioni. In B. Pinelli (Ed.), Migrazioni e Asilo Politico, Antropologia, 13(15), 131-151.

Sorgoni, B. (under review). The Location of Truth. Bodies and Voices in the Italian Asylum Procedure. PoLAR: Political and Legal Anthropology Review.

Sorgoni, B., \& Viazzo, P. P. (2010). Documenti. In C. Pennacini (Ed.), La ricerca sul campo in antropologia. Oggetti e metodi (pp. 323-45). Roma: Carocci. 
Souter, J. (2011). A Culture of Disbelief or Denial? Critiquing Refugee Status Determination in the United Kingdom. Oxford Monitor of Forced Migration, 1(1), 48-59.

Stoler, A. L. (2009). Along the Archival Grain. Epistemic Anxieties and Colonial Common Sense. Princeton and Oxford: Princeton University Press.

Sweeney, J. A. (2009). Credibility, Proof and Refugee Law. International Journal of Refugee Law, 21(4), 700-726.

Tazzioli, M., \& De Genova, N. (2016). Europe/Crisis: Introducing New Keywords of 'the Crisis' In And of 'Europe'. In N. De Genova \& M. Tazzioli (Eds.), Europel Crisis: New Keywords of the Crisis' In And of 'Europe'. Zone Books online. http:// nearfuturesonline.org/europecrisis-new-keywords-of-crisis-in-and-of-europe/.

Tuckett, A. (2015). Strategies of Navigation: Migrants' Everyday Encounters with Italian Immigration Bureaucracy. The Cambridge Journal of Anthropology, 33(1), $113-128$.

Tuckett, A. (2016). Moving on: Italy as a Stepping Stone in Migrants' Imaginaries. Focaal, 76, 99-113.

UNHCR. (1979). Handbook on Procedures and Criteria for Determining Refugee Status. Geneva. Available at: www.unhcr.org.

UNHCR. (1998). Note on Burden and Standard of Proof in Refugee Claims. Geneva. Available at: http://www.unhcr.org/.

UNHCR. (2013). Beyond Proof. Credibility Assessment in EU Asylum Systems. Geneva. Available at: http://www.unhcr.org/.

Vacchiano, F. (2011). Discipline della scarsità e del sospetto: rifugiati e accoglienza nel regime di frontiera. Lares, 77(1), 181-198.

Open Access This chapter is distributed under the terms of the Creative Commons Attribution 4.0 International License (http://creativecommons.org/licenses/ by/4.0/), which permits use, duplication, adaptation, distribution and reproduction in any medium or format, as long as you give appropriate credit to the original author(s) and the source, a link is provided to the Creative Commons license and any changes made are indicated.

The images or other third party material in this chapter are included in the work's Creative Commons license, unless indicated otherwise in the credit line; if such material is not included in the work's Creative Commons license and the respective action is not permitted by statutory regulation, users will need to obtain permission from the license holder to duplicate, adapt or reproduce the material. 